\title{
PENGARUH PERBEDAAN SUHU AWAL AIR RENDAMAN DAN LAMA PERENDAMAN TERHADAP PERKECAMBAHAN BENIH GMELINA (Gmelina arborea Roxb.)
}

\author{
Miranda H. Hadijah \\ Staf Pengajar FAPERTA UNPATI-Ambon, e-mail: -
}

\begin{abstract}
ABSTRAK
Penelitian ini bertujuan untuk mengetahui pengaruh faktor suhu, lama perendaman dan interaksinya terhadap perkecambahan benih Gmelina arborea Roxb. Penelitian dilakukan dengan percobaan faktorial $3 \times 3$ dalam RAL. Faktor pertama adalah suhu $\left(50,60\right.$ dan $\left.70^{\circ} \mathrm{C}\right)$ dan faktor kedua adalah lama perendaman $(6,12$ dan 24 jam) dengan 3 kali ulangan dan setiap unit percobaan berisi 20 butir benih. Hasil menunjukkan bahwa perlakuan yang diberikan tidak berpegaruh nyata terhadap persen berkecambah, masa berkecambah dan kecepatan berkecambah..
\end{abstract}

Kata Kunci: Gmelina, perkecambahan

\section{PENDAHULUAN}

Dalam rangka untuk menyediakan keseragaman benih yang akan ditanam salah satu hal yang mempengaruhi adalah keseragaman waktu berkecambah. Hal tersebut dapat dilakukan dengan memberi perlakuan (skarifikasi). Sakarifikasi dilakukan untuk mematahkan dormansi dan mempercepat proses perkecambahan benih. Salah satu cara skarifikasi benih secara fisik adalah dengan merendam benih dalam air dingin atau air panas (Soeseno, 1978).

Gmelina arborea Roxb. termasuk suku Verbanaceae yang biasa hidup dalam kelompok-kelompok besar, kadang-kadang becampur dengan tegakan jati (Tectona grandis). Sifat kayu G. arborea Roxb, tergolong dalam kelas awet menengah, kadar air berkisar antara $12-15 \%$, mudah dikerjakan dan tahan terhadap cuaca. Kayunya sering dipakai sebagai bahan konstruksi bangunan, pulp, kertas dan batang korek api. Dilihat dari kegunaannya maka G. arborea Roxb. memiliki prospek yang cukup baik untuk dikembangkan baik pada hutan tanaman maupun sebagai tanaman rehabilitasi/pengayaan sebagai salah satu alternatif dalam rangka mengatasi kebutuhan kayu yang semakin meningkat meskipun $G$. arborea Roxb bukan tanaman asli Indonesia.
Permasalahan yang sering muncul adalah bagaimana mengecambahkan benih $G$. arborea Roxb karena benih G. arborea Roxb. termasuk benih yang berkulit keras untuk itu perlu dilakukan skarifikasi untuk mempercepat proses perkecambahan dengan merendam benih dalam air selama $24 \quad-48$ jam (Bratawinata, 1978). Kebanyakan benih berkecambah dengan temperatur tanah kirakira $30{ }^{\circ} \mathrm{C}$. Sebagian memerlukan temperatur yang lebih tinggi teristimewa $G$. arborea Roxb dan Tectona grandis yang memerlukan temperatur $55{ }^{\circ} \mathrm{C}$ (Soetrisno, 2001).

Berdasarkan hal tersebut di atas, penelitian ini bertujuan untuk mengetahui pengaruh faktor suhu awal perendaman, lama perendaman dan interaksi kedua faktor tersebut terhadap perkecambahan benih G.arborea Roxb.

Penelitian ini diharapkan dapat memberi masukan bagi masyarakat dan pihak-pihak terkait seperti pemegang Hak Pengusahaan Hutan (IUPHHK) dalam pembangunan hutan alam maupun Hutan Tanaman Industri (HTI).

\section{METODE PENELITIAN}

2.1. Tempat dan Waktu Penelitian

Penelitian ini dilaksanakan di Kota Ambon selama 3 bulan. 


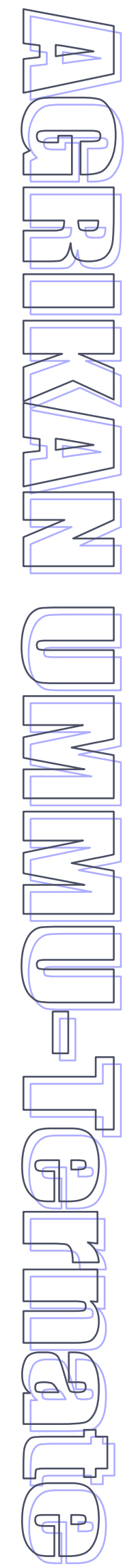

\subsection{Alat dan Bahan}

Alat yang digunakan dalam penelitian ini adalah Thermometer, kalkulator, gelas, papan, mistar/meteran, mikrokaliper dan alat tulis menulis. Sedangkan bahan yang digunakan adalah: Biji G. arborea Roxb., tanah hutan, pasir, air dan polybag.

\subsection{Rancangan Penelitian}

Penelitian ini menggunakan percobaan faktorial A x B, masing-masing $A=3$ taraf dan $B=3$ taraf yang disusun dalam Rancangan Acak Lengkap (RAL), perinciannya sebagai berikut:

a. Faktor A, suhu (s) terdiri dari 3 tingkat, yaitu:

$\mathrm{s}_{1}=$ Suhu $50^{\circ} \mathrm{C}$

$\mathrm{S}_{2}=$ Suhu $60^{\circ} \mathrm{C}$

$\mathrm{s}_{3}=\mathrm{Suhu} 70^{\circ} \mathrm{C}$

b. Faktor B, lama perendaman (p) terdiri dari 3 tingkat, yaitu:

$\mathrm{p}_{1}=$ Perendaman selama 6 jam

$\mathrm{p}_{2}=$ Perendaman selama 12 jam

$\mathrm{p}_{3}=$ Perendaman selama 24 jam

Jumlah seluruh satuan percobaan adalah

9 perlakuan $\times 3$ ulangan $\times 20$ sampel $=540$ tanaman.

Model matematikanya sebagai berikut:

$$
Y_{i j k}=\mu+\alpha_{i}+\beta_{j}+(\alpha \beta)_{i j}+\varepsilon_{i j k}
$$

Di mana :

$$
\begin{array}{ll}
\mathrm{Y}_{\mathrm{ijk}}= & \text { Nilai pengamatan perlakuan } \\
& \text { dari faktor } \mathrm{A}, \text { taraf } \mathrm{i} \text { dan faktor } \\
& \mathrm{B} \text { taaf } \mathbf{j} \text { masing-masing } \\
& \text { dirandom pada ulangan } \mathrm{k} . \\
\mu & \text { Nilai rata-rata harapan } \\
\alpha_{\mathrm{I}} & =\text { Pengaruh fakor } \mathrm{A} \text { taraf } \mathbf{i} \\
\beta_{\mathrm{j}} & =\text { Pengaruh fakor } \mathrm{B} \text { taraf } \mathbf{j} \\
(\alpha \beta) \mathrm{ij}= & \text { Interaksi antara } \alpha \text { dan } \beta_{\mathrm{j}} \\
\varepsilon_{\mathrm{ijk}}= & \text { Galat percobaan }
\end{array}
$$

\subsection{Prosedur Penelitian}

\subsubsection{Persiapan Media}

Seminggu sebelum penyemaian telah disiapkan alat dan bahan yang akan digunakan dalam penelitian dengan langkah-langkah sebagai berikut:

a. Pembuatan petak percobaan dengan ukuran $300 \mathrm{~cm} \times 150 \mathrm{~cm}$ yang terbuat dari papan kemudian petak percobaan tersebut di bagi dalam 27 plot. b. Pemasangan nomor plot percobaan, label perlakuan dan nomor ulangan yang di tentukan dengan menggunakan lotre

c. Pencampuran media tanah hutan dan pasir dengan perbandingan 2:1 yang telah disterilkan dengan cara menjemur selama 2 hari, selanjutnya diisi dalam polybag sebanyak 540 kemudian di masukan ke dalam plot percobaan masing-masing sebanyak 20 polybag.

d. Pengadaan benih di peroleh dari laboratorium Bioteknologi Fakultas Kehutanan IPB Bogor. Sebelum diberi perlakuan terlebih dahulu di seleksi dengan cara merendam benih dalam air, benih yang tenggelam di ambil untuk digunakan dalam penelitian. Benih di ambil secara acak di maksudkan untuk menghindari pengaruh ukuran benih.

\subsubsection{Tahap Pelaksanaan}

a. Menyediakan 27 buah gelas yang telah diberi label perlakuan $S_{1} P_{1}(1), S_{1} P_{2}(2)$, $\mathrm{S}_{1} \mathrm{P}_{3}(3), \ldots . . \mathrm{S}_{3} \mathrm{P}_{3}(3)$.

b. Pemberian perlakuan dengan cara :

> Sembilan gelas pertama diisi air panas dengan suhu awal $50^{\circ} \mathrm{C}$ kemudian dimasukan masing-masing gelas 20 benih dan tiap tiga gelas dibiarkan masingmasing selama 6, 12 dan 24 jam.

$>$ Sembilan gelas kedua diisi air panas dengan suhu awal $60^{\circ} \mathrm{C}$ kemudian dimasukan masing-masing gelas 20 benih dan tiap tiga gelas di biarkan masingmasing selama 6, 12 dan 24 jam.

$>$ Sembilan gelas ketiga diisi air panas dengan suhu awal $70^{\circ} \mathrm{C}$ kemudian dimasukan masing-masing gelas 20 benih dan tiap tiga gelas di biarkan masingmasing selama 6, 12 dan 24 jam.

c. Penyemaian

Setelah benih di beri perlakuan sesuai dengan prosedur, benih selanjutnyadi semaikan di polybag.

d. Pemeliharaan

Untuk mempertahankan kelembaban di lakukan penyiraman secukupnya pada pagi dan sore hari.

\subsection{Pengumpulan Data.}

Pengamatan dan pengumpulan data perkecambahan di lakukan setiap hari sejak 
सज्ञ

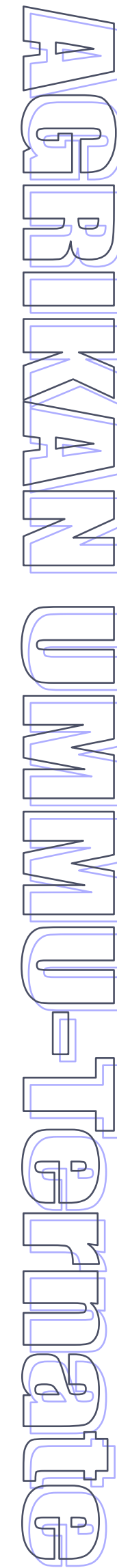

penaburan benih sampai akhir penelitian. Parameter yang di ambil antara lain

1. Persen Kecambah (PK, \%). Merupakan nilai perbandingan antara jumlah benih yang berkecambah sampai saat pengujian benih di lakukan dengan jumlah keseluruhan benih yang di gunakan dan dapat di hitung dengan rumus Sutopo (1985), dilaksanakan setelah benih di beri perlakuan.

$\%$ Kecambah $=\frac{\text { Jumlah Benih Yang Berkecambah }}{\text { Jumlah Benih Yang di Semaikan }} \times 100 \%$

2. Masa Berkecambah (MK, Hari). Pengamatan masa berkecambah dilakukan sejak benih mulai berkecambah hingga benih tidak lagi berkecambah untuk tiap perlakuan.

3. Kecepatan Berkecambah (KK, Benih/Hari). Diukur dengan menghitung jumlah hari yang diperlukan untuk munculnya radikel dan plumula, pengamatan dilakukan setiap hari sejak benih mulai berkecambah dengan menggunakan rumus:

$$
\text { Kecepatan berkecambah }=\frac{N_{1} T_{1}+N_{2} T_{2} \ldots+N_{x} T_{x}}{N_{1}+N_{2}+\ldots+N_{x}}
$$

Dimana :

$$
\begin{aligned}
\mathbf{N}= & \begin{array}{l}
\text { Jumlah benih yang } \\
\text { berkecambah pada satuan }
\end{array} \\
& \begin{array}{r}
\text { waktu tertentu. } \\
\mathrm{T}=
\end{array} \\
& \begin{array}{l}
\text { Waktu yang bersesuaian dengan } \\
\text { jumlah benih tersebut. }
\end{array}
\end{aligned}
$$

\subsection{Analisis Data}

Data dianalisis secara statistik dengan menggunakan analisis sidik ragam dan di lanjutkan dengan uji - F.

Menurut Gomez dan Gomez (1967), nilai pengamatan dalam angka relatif (satuan \%) sebelum di analisis secara statistik maka pelu di tranformasikan dengan ketentuan sebagai berikut :

1. Jika nilai pengamatan (x) berkisar antara 0 - $30 \%$, maka data ditranformasikan menjadi $X+0,5$.

2. Jika nilai (x) berkisar antara $30-70 \%$, maka tidak perlu ditranformasikan.
3. Jika nilai (x) berkisar antara $0-100 \%$, maka data ditransformasikan menjadi $x^{\prime}$, dengan catan sebelum ditransformasikan nilai $x=0$ diubah menjadi $1 / 4 n$, nilai $x=100$ di ubah menjadi $100-1 / 4 n$ dimana $n$ adalah jumlah ulangan.

Data perkecambahan selain di analisis dengan rancangan percobaan juga di hitung nilai simpangan baku/standar deviasi (Sd) dan galat baku/standar error (Se) untuk mengetahui seberapa besar derajat penyimpangan dan derajat kesalahan data.

\section{HASIL DAN PEMBAHASAN}

\subsection{Hasil Penelitian}

\subsubsection{Persen Berkecambah}

Hasil analisis sidik ragam menunjukan bahwa faktor suhu, faktor lama perendaman dan interaksi antara kedua faktor tersebut tidak berpengaruh nyata terhadap persen berkecambah benih seperti yang diperlihatkan dalam Tabel 1.

Benih G. arborea yang telah di rendam dengan suhu awal 50, 60 dan $70{ }^{\circ} \mathrm{C}$ masingmasing selama 6, 12 dan 24 jam telah menghasilkan rata-rata persen berkecambah yang beragam. Nilai kombinasi rata-rata persen berkecambah setelah 5 minggu sejak penyemaian adalah maksimum $90,00 \%$ pada kombinasi perlakuan suhu awal $50^{\circ} \mathrm{C}$ dengan lama perendaman 12 jam, dan minimum 73,33 $\%$ pada kombinasi perlakuan suhu awal $50^{\circ} \mathrm{C}$ dengan lama perendaman 6 jam. Sementara nilai galat baku (Standard error) terbaik pada kombinasi perlakuan $70^{\circ} \mathrm{C}$ dan lama perendaman 24 jam dengan nilai 0.00. seperti diperlihatkan dalam Gambar 1.

Perendaman benih dengan suhu awal air rendaman 50, 60 dan $70{ }^{\circ} \mathrm{C}$ menghasilkan rataan persen berkecambah masing-masing secara berurutan 83,$89 ; 80,00$ dan $77,78 \%$ dengan nilai Se masing-masing 2,98; 2,89; dan 1,69 seperti yang diperllihatkan dalam Gambar 2. 

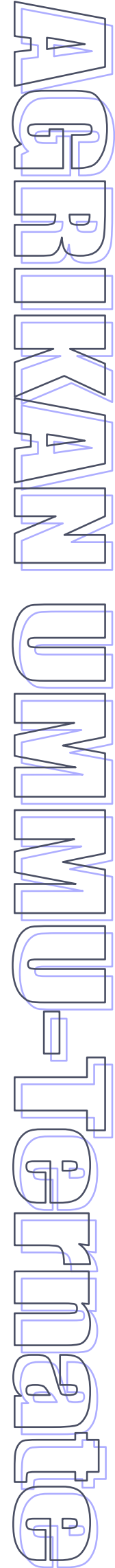

Tabel 1. Analisis Sidik Ragam Pengaruh Suhu dan Lama Perendaman pada Persen Berkecambah Benih.

\begin{tabular}{|c|c|c|c|c|c|c|}
\hline \multirow{2}{*}{$\begin{array}{c}\text { Sumber } \\
\text { Keragaman }\end{array}$} & \multirow{2}{*}{$\begin{array}{l}\text { Derajat } \\
\text { Bebas }\end{array}$} & \multirow{2}{*}{$\begin{array}{l}\text { Jumlah } \\
\text { Kuadrat }\end{array}$} & \multirow{2}{*}{$\begin{array}{l}\text { Kuadrat } \\
\text { Tengah }\end{array}$} & \multirow{2}{*}{$F_{\text {Hitung }}$} & \multicolumn{2}{|c|}{$F_{\text {Tabel }}$} \\
\hline & & & & & $5 \%$ & $1 \%$ \\
\hline Suhu & 2 & 121,3922 & 60,69608 & $2,1576^{\text {tn }}$ & 3,55 & 6,01 \\
\hline Lama Perendaman & 2 & 95,3208 & 67,6604 & $1,6842^{\mathrm{tn}}$ & 3,55 & 6,01 \\
\hline Interaksi & 4 & 229,4954 & 57,3738 & $2,0395^{\text {tn }}$ & 2,93 & 4,58 \\
\hline Galat & 18 & 506,3673 & 28,1315 & & & \\
\hline Total & 26 & 925,5757 & & & & \\
\hline
\end{tabular}

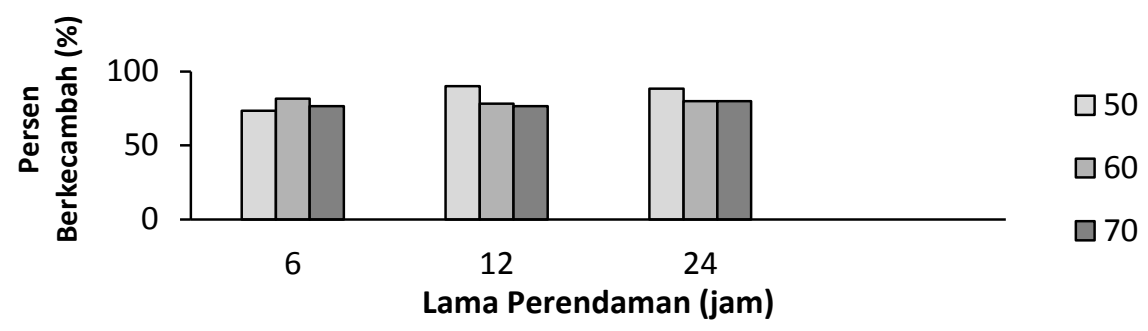

Gambar 1. Persen Berkecambah benih G. arborea yang telah di rendam dengan suhu awal 50, 60 dan $70{ }^{\circ} \mathrm{C}$ masing-masing 6, 12 dan 24 jam, selama 5 minggu setelah penyemaian.

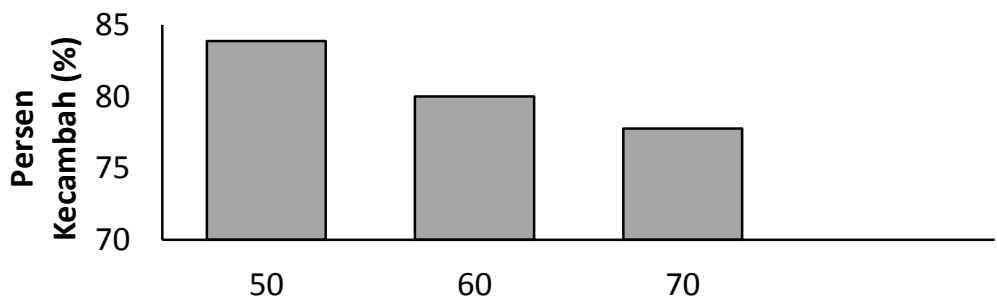

Gambar 2. Rataan suhu awal 50,60 dan $70^{\circ} \mathrm{C}$ pada persen berkecambah (PK, \%) benih G. arborea selama 5 minggu setelah penyemaian.

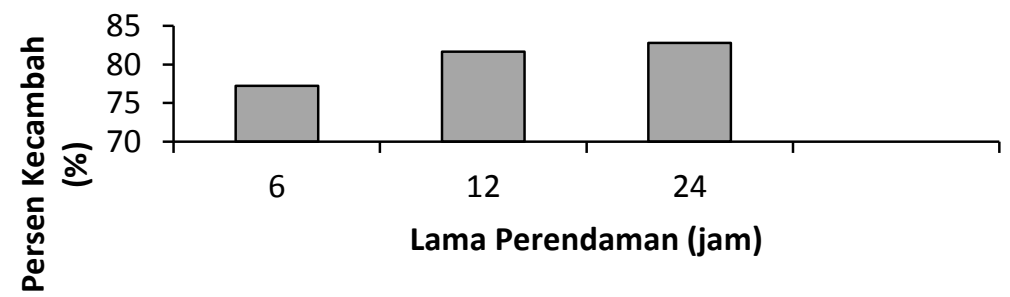

Gambar 3. Rataan Lama perendaman 6, 12 dan 24 jam pada persen berkecambah (PK, \%) benih G. arborea selama 5 minggu setelah penyemaian.

Sementara lama perendaman 6, 12 dan 24 jam masing-masing secara berurutan menghasilkan persen berkecambah rataan 77,$22 ; 81,67$; dan $82,78 \%$, sementara nilai Se. masing-masing
2,06; 2,89; dan 2,78 seperti yang di perlihatkan dalam Gambar 3.

\subsubsection{Masa Berkecambah}

Hasil analisis sidik ragam menunjukan bahwa faktor suhu, faktor lama perendaman dan 

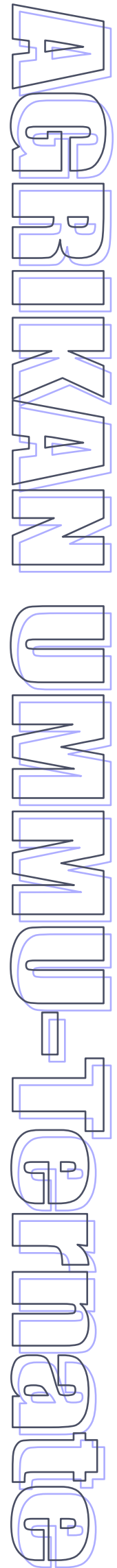

interaksi antar kedua faktor tersebut tidak berpengaruh nyata terhadap masa berkecambah benih se perti yang di perlihatkan dalam Tabel 2.

Benih G. arborea yang di rendam dengan suhu awal air rendaman 50, 60 dan $70{ }^{\circ} \mathrm{C}$ menghasilkan masa berkecambah rataan masing-masing secara berurutan 15,89; 15,78 dan 16,67 hari; dengan nilai Se. masing-masing 0,79; 0,72 dan 0,90 seperti yang diperlihatkan dalam Gambar 4.

Tabel 2. Analisis Sidik Ragam Pengaruh Suhu Dan Lama Perendaman Pada Masa Berkecambah Benih.

\begin{tabular}{lcccccc}
\hline $\begin{array}{c}\text { Sumber } \\
\text { Keragaman }\end{array}$ & $\begin{array}{c}\text { Derajat } \\
\text { Bebas }\end{array}$ & $\begin{array}{c}\text { Jumlah } \\
\text { Kuadrat }\end{array}$ & $\begin{array}{c}\text { Kuadrat } \\
\text { Tengah }\end{array}$ & F Hitung & \multicolumn{2}{c}{ F Tabel } \\
\cline { 6 - 8 } & 2 & 4,2222 & 2,111 & 0,3098 tn & 3,55 & 6,01 \\
Suhu & 2 & 2,0000 & 1,000 & $0,1467^{\text {tn }}$ & 3,55 & 6,01 \\
Lama Perendaman & 4 & 15,7778 & 3,944 & $0,5788^{\text {tn }}$ & 2,93 & 4,58 \\
Interaksi & 18 & 122,6667 & 6,814 & & & \\
Galat & 26 & 144,6667 & & & \\
\hline Total & & &
\end{tabular}

Keterangan : $t n=$ tidak nyata

Lama perendaman 6, 12 dan 24 jam menghasilkan masa berkecambah rataan masing-masing secara berurutan 16,$44 ; 16,11$ dan 15,78 hari dengan nilai Se. masing-masing 0,$96 ; 0,54$ dan 0,64 seperti yang di sajikan dalam Gambar 5.

Perendaman benih dengan suhu awal $50^{\circ} \mathrm{C}, 60^{\circ} \mathrm{C}$ dan $70^{\circ} \mathrm{C}$ masing-masing selama 6,12 dan 24 jam telah menghasilkan rata-rata tertinggi 17,67 hari pada kombinasi perlakuan suhu awal $50^{\circ} \mathrm{C}$ dengan lama perendaman 6 jam, dan terendah 14,67 hari pada kombinasi perlakuan suhu awal $50^{\circ} \mathrm{C}$ dengan lama perendaman24 jam sementara nilai Se. terbaik pada kombinasi perlakuan $50^{\circ} \mathrm{C} ; 24$ jam, dan $70^{\circ} \mathrm{C}$; 12 jam dengan nilai 0,33 , seperti di perlihatkan dalam Gambar 6.

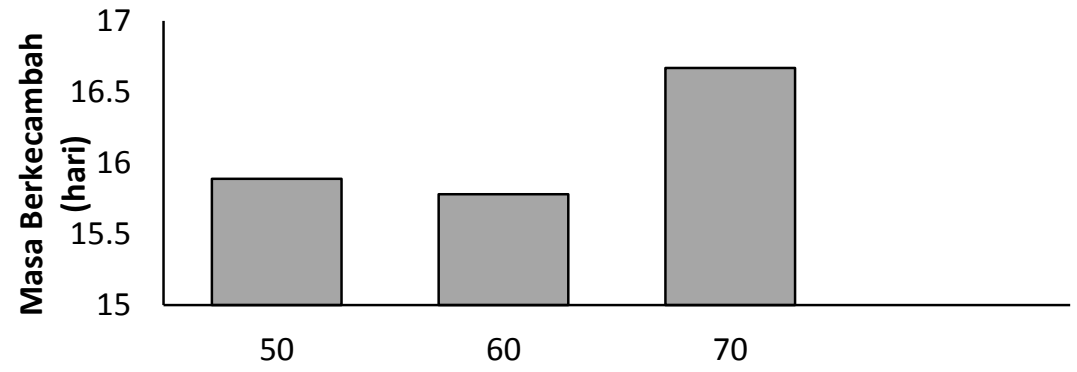

Gambar 4. Rataan Suhu awal 50, 60 dan $70^{\circ} \mathrm{C}$ pada Masa Berkecambah (MK, hari) benih G. arborea setelah 5 minggu setelah penyemaian.

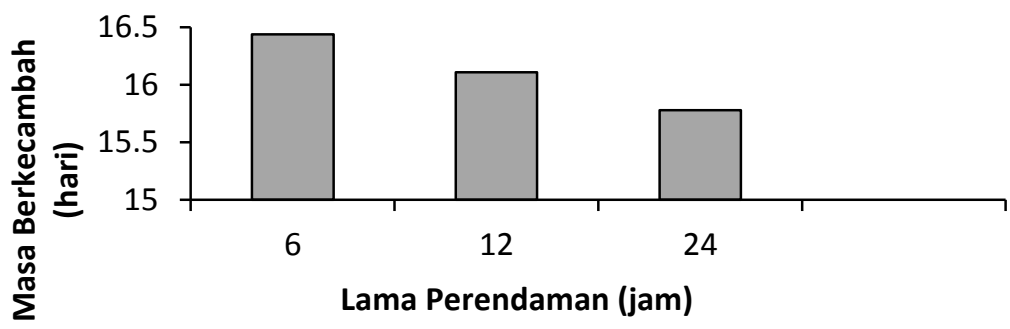

Gambar 5. Rataan Lama Perendaman 6, 12 dan 24 jam pada Masa Berkecambah (MK, hari) benih G. arborea selama 5 minggu Setelah Penyemaian. 

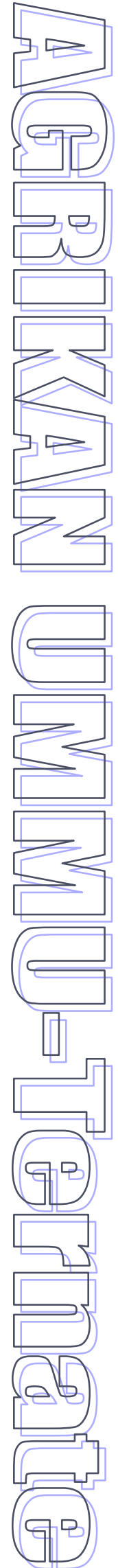

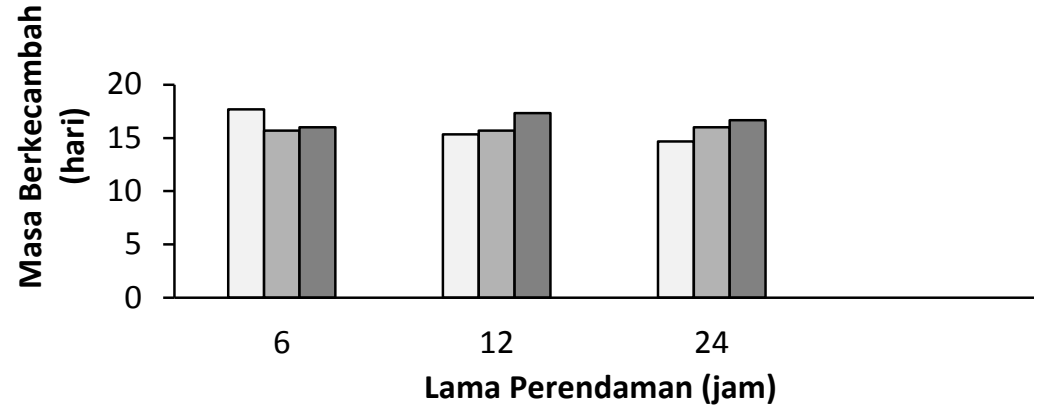

Gambar 6. Masa Berkecambah Benih G. arborea yang Telah Direndam dengan Suhu Awal 50, 60 dan 70 C Masing-masing 6, 12 dan 24 jam, Selama 5 minggu Setelah Penyemaian.

\subsubsection{Kecepatan Berkecambah}

Berdasarkan hasil analisis sidik ragam ternyata faktor suhu, faktor lama perendaman dan interaksi antar kedua faktor tersebut tidak berpengaruh terhadap kecepatan berkecambah benih seperti yang diperlihatkan dalam Tabel 3.

Perendaman benih dengan suhu awal 50, 60 dan $70^{\circ} \mathrm{C}$ dengan lama perendaman masingmasing 6, 12 dan 24 jam telah menghasilkan kecepatan berkecambah benih rata-rata tercepat 9,80 benih/hari pada kombinasi perlakuan suhu awal $50^{\circ} \mathrm{C}$ dengan lama perendaman 24 jam dan terlambat 12,96 benih/hari pada kombinasi perlakuan suhu awal $70^{\circ} \mathrm{C}$ dengan lama perendaman 12 jam seperti tersaji pada Gambar 7.

Benih yang telah di rendam dengan suhu awal 50, 60 dan $70^{\circ} \mathrm{C}$ menghasilkan kecepatan berkecambah rataan masing-masing secara berurutan 10,45; 11,00 dan 12,06 benih/hari dengan Se. masing-masing 0,47;0,39 dan 0,49 seperti diperlihatkan pada gambar Gambar 8 .

Lama perendaman 6 jam, 12 jam dan 24 jam telah menghasilkan kecepatan berkecambah rataan masing-masing secara berurutan 11,32; 11,61 dan 10,58 benih/hari dengan nilai Se. masing-masing 0,50; 0,51 dan 0,44 yang diperlihatkan pada Gambar 9 .

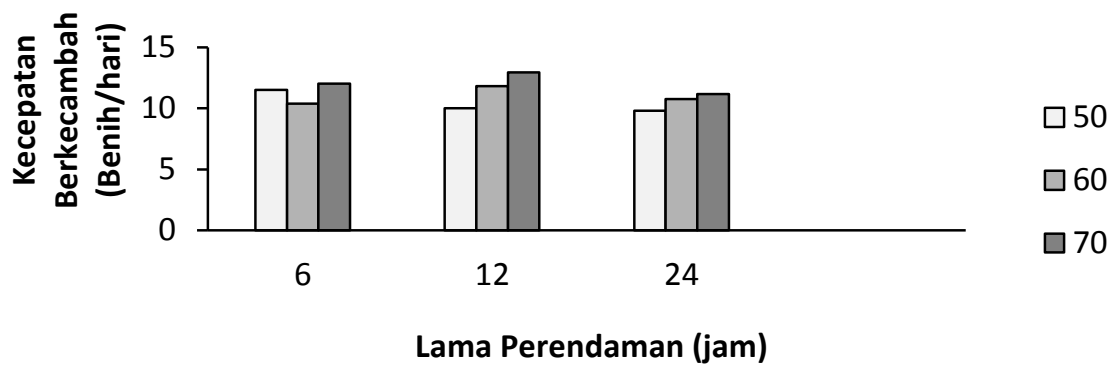

Gambar 7. Kecepatan berkecambah benih $G$. arborea yang telah direndam dengan Suhu awal 50, 60 dan $70^{\circ} \mathrm{C}$ masing-masing selama 6, 12 dan 24 jam, selama 5 minggu setelah penyemaian.

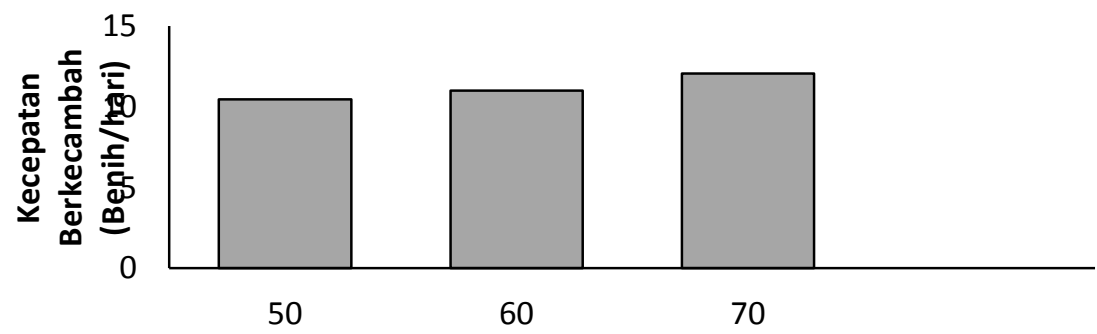

Gambar 8. Rataan Suhu Awal 50, 60 dan $70^{\circ} \mathrm{C}$ pada Kecepatan Berkecambah (KK, benih/hari) Benih G. arborea Selama 5 minggu Setelah Penyemaian. 

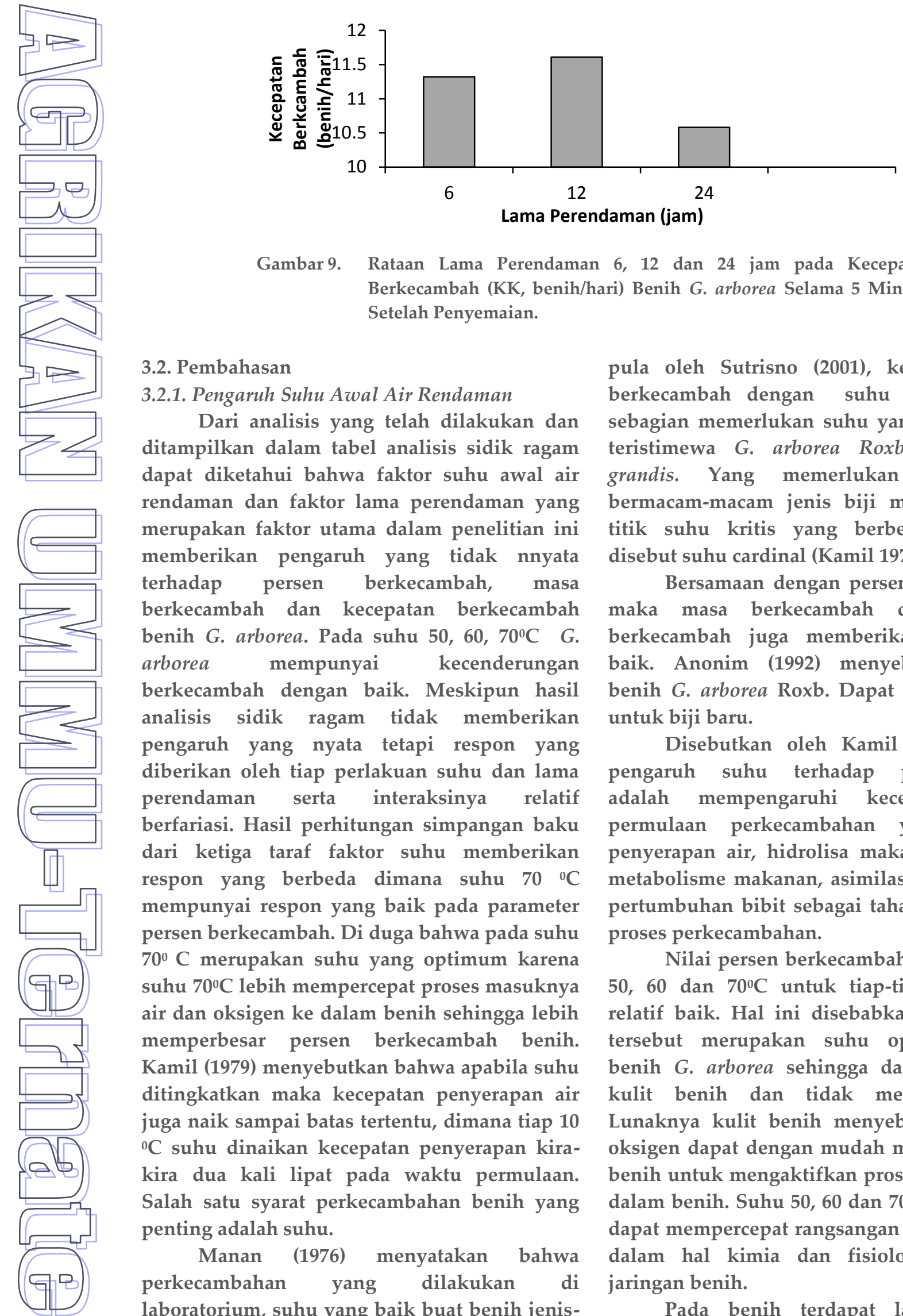

Gambar 9. Rataan Lama Perendaman 6, 12 dan 24 jam pada Kecepatan Berkecambah (KK, benih/hari) Benih G. arborea Selama 5 Minggu Setelah Penyemaian.

\subsection{Pembahasan}

\subsubsection{Pengaruh Suhu Awal Air Rendaman}

Dari analisis yang telah dilakukan dan ditampilkan dalam tabel analisis sidik ragam dapat diketahui bahwa faktor suhu awal air rendaman dan faktor lama perendaman yang merupakan faktor utama dalam penelitian ini memberikan pengaruh yang tidak nnyata terhadap persen berkecambah, masa berkecambah dan kecepatan berkecambah benih $G$. arborea. Pada suhu 50, 60, 70 $\mathrm{C} G$. arborea mempunyai kecenderungan berkecambah dengan baik. Meskipun hasil analisis sidik ragam tidak memberikan pengaruh yang nyata tetapi respon yang diberikan oleh tiap perlakuan suhu dan lama perendaman serta interaksinya relatif berfariasi. Hasil perhitungan simpangan baku dari ketiga taraf faktor suhu memberikan respon yang berbeda dimana suhu $70{ }^{\circ} \mathrm{C}$ mempunyai respon yang baik pada parameter persen berkecambah. Di duga bahwa pada suhu $70^{\circ} \mathrm{C}$ merupakan suhu yang optimum karena suhu $70^{\circ} \mathrm{C}$ lebih mempercepat proses masuknya air dan oksigen ke dalam benih sehingga lebih memperbesar persen berkecambah benih. Kamil (1979) menyebutkan bahwa apabila suhu ditingkatkan maka kecepatan penyerapan air juga naik sampai batas tertentu, dimana tiap 10 ${ }^{0} \mathrm{C}$ suhu dinaikan kecepatan penyerapan kirakira dua kali lipat pada waktu permulaan. Salah satu syarat perkecambahan benih yang penting adalah suhu.

Manan (1976) menyatakan bahwa perkecambahan yang dilakukan di laboratorium, suhu yang baik buat benih jenisjenis pohon berkisar antara $20-30^{\circ} \mathrm{C}$ kecuali Jati yang memerlukan suhu $55^{\circ} \mathrm{C}$. Dijelaskan pula oleh Sutrisno (2001), kebanyakan biji berkecambah dengan suhu kira-kira $30^{\circ} \mathrm{C}$. sebagian memerlukan suhu yang lebih tinggi, teristimewa G. arborea Roxb dan Tectona grandis. Yang memerlukan suhu $50^{\circ} \mathrm{C}$. bermacam-macam jenis biji mempunyai tiga titik suhu kritis yang berbeda-beda, yang disebut suhu cardinal (Kamil 1979).

Bersamaan dengan persen berkecambah, maka masa berkecambah dan kecepatan berkecambah juga memberikan hasil yang baik. Anonim (1992) menyebutkan bahwa benih G. arborea Roxb. Dapat mencapai $95 \%$ untuk biji baru.

Disebutkan oleh Kamil (1979), bahwa pengaruh suhu terhadap perkecambahan adalah mempengaruhi kecepatan proses permulaan perkecambahan yang meliputi penyerapan air, hidrolisa makanan cadangan, metabolisme makanan, asimilasi, respirasi dan pertumbuhan bibit sebagai tahap terakhir dari proses perkecambahan.

Nilai persen berkecambah, diantara suhu 50, 60 dan $70^{\circ} \mathrm{C}$ untuk tiap-tiap perlakuan relatif baik. Hal ini disebabkan karena suhu tersebut merupakan suhu optimum untuk benih G. arborea sehingga dapat melunakan kulit benih dan tidak merusak embrio. Lunaknya kulit benih menyebabkan air dan oksigen dapat dengan mudah masuk ke dalam benih untuk mengaktifkan proses metabolisme dalam benih. Suhu 50, 60 dan $70^{\circ} \mathrm{C}$ juga diduga dapat mempercepat rangsangan terhadap benih dalam hal kimia dan fisiologi di seluruh jaringan benih.

Pada benih terdapat lapisan khusus berupa sel hidup yang sering disebut aleuron melingkari jaringan utama endosperm dan 


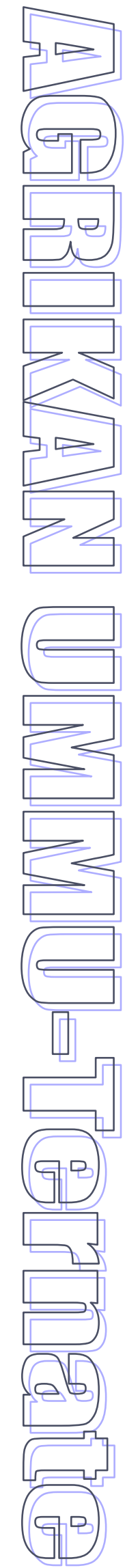

merupakan alat pencerna bahan makanan yang tersimpan menjadi bentuk yang dapat larut dan berdifusi ke dalam embrio. Pada saat benih akan berkecambah, air berdifusi ke lapisan aleuron dan memacu sintesa enzim untuk mencerna cadangan makanan yang tersimpan dalam endosperm. Sehingga menyebabkan dimulainya perombakan karbohidrat, lemak dan protein. Senyawa-senyawa rombakan ini akan larut, berdifusi dan ditranslokasikan ke titik tumbuh serta disusun kembali menjadi protein baru (Kamil, 1979; Juctice dan Bass 1994 dalam Triwanto 1997).

\subsubsection{Pengaruh Lama Perendaman}

Lama perendaman tidak memberikan pengaruh yang nyata terhadap persen berkecambah, masa berkecambah dan kecepatan berkecambah benih

Benih G. arborea Roxb. tergolong benih yang berkulit keras yang memerlukan perlakuan perendaman dalam jangka waktu tertentu supaya kulit benih menjadi lunak untuk mempercepat proses perkecambahan. Benih G. arborea di rendam selama 12-48 jam adalah untuk melunakan kulit biji dan mempercepat perkecambahan (Bratawinata, 1987).

Perendaman benih G. Arborea Roxb. selama 6, 12 dan 24 jam telah mempercepat masa berkecambah, kecepatan berkecambah dan memberikan nilai yang cukup baik terhadap persen berkecambah.

Tingginya angka-angka dari semua parameter penelitian tersebut disebabkan karena lama perendaman 6, 12 dan 24 jam merupakan lama perendaman yang efektif dan efisien untuk benih $G$. arborea Roxb. rataan lama perendaman tiap perlakuan menunjukan nilai yang tinggi dan mempunyai perbedaan yang satu sama lain tidak terlalu jauh seperti yang diperlihatkan dalam tabel-tabel hasil penelitian.

Perendaman benih dalam air yang terlalu lama akan menyebabkan daya berkecambah dan persen berkecambah benih menurun karena benih menyerap air yang berlebihan, sehingga mencapai titik jenuh dan mengakibatkan penurunan kemampuan berkecambah. Lama perendaman 6-12 jam merupakan lama perendaman yang optimal untuk perkecambahan benih G. arborea Roxb. bila di kombinasikan dengan suhu awal air rendaman 50,60 dan $70^{\circ} \mathrm{C}$.

Air memegang peraranan penting dalam perkecambahan. Air merupakan faktor yang menentukan dalam kehidupan awal tumbuhan. Fungsi air menurut Kamil (1979), adalah melunakan kulit biji dan menyebabkan pengembangan embrio dan endosperm, memberikan fasilitas untuk masuknya oksigen ke dalam benih untuk menngencerkan protoplasma sehingga dapat mengaktifkan berbagai macam fungsinya dan berguna sebagai alat transportasi larutan makanan dari endosperm.

\section{KESIMPULAN DAN SARAN}

4.1. Kesimpulan

1. Diantara suhu awal air rendaman 50,60 dan $70^{\circ} \mathrm{C}$ tidak terdapat perbedaan yang nyata dalam menghasilkan persen, masa dan kecepatan berkecambah benih $G$. arborea Roxb.

2. Untuk lama perendaman 6, 12 dan 24 jam tidak terdapat perbedaan yang nyata dalam menghasilkan persen, masa dan kecepatan berkecambah benih $G$. arborea Roxb.

3. Interaksi antara faktor suhu awal air rendaman dan lama perendaman tidak berpengaruh nyata terhadap persen, masa dan kecepatan berkecambah benih $G$. arborea Roxb.

4. Hasil perhitungan simpangan baku dari tiap perlakuan, menunjukan bahwa suhu $70^{\circ} \mathrm{C}$ dan lama perendaman 6 jam memberikan respon yang terbaik untuk persen berkecambah. Sedangkan suhu $50^{\circ} \mathrm{C}$ dengan lama perendaman 24 jam memberikan respon yang terbaik untuk masa berkecambah dan kecepatan berkecambah.

\subsection{Saran}

1. Untuk mendapatkan persen berkecambah yang terbaik pada benih G. arborea maka perendamannya dengan suhu awal $70^{\circ} \mathrm{C}$ dengan lama perendaman 6 jam.

2. Perlu penelitian dengan menggunakan skarifikasi fisik dan kimia untuk mengetahui persen berkecambah. 


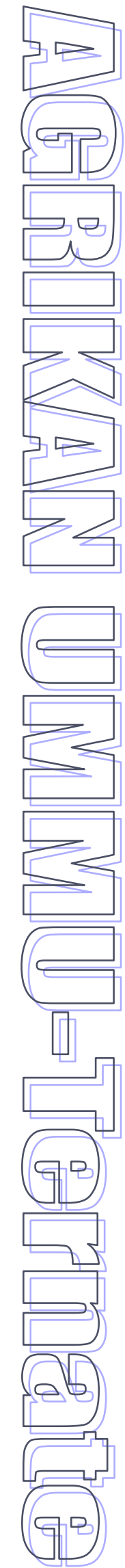

\section{DAFTAR PUSTAKA}

Anonim, 1992. Teknik Penanaman dan Pemungutan Hasil Gmelina arborea Yamane. Pusat Penelitian dan Pengembangan Hutan. Bogor.

Bratawinata, A. A., 1987. Beberapa Catatan dari Pohon-pohon Industri cepat Tumbuh. Fakultas Kehutanan. Universitas Mulawarman. Samarinda.

Gomez, K. A. and Gomez A. A., Statistical Procedure for Agricultural Research Institut. Los Banos. Laguna. Philippines.

Kamil, J. 1979. Teknologi Benih. Angkasa Raya. Padang.

Manan, S., 1976. Silvikultur. Lembaga Kerjasama Fakultas Kehutanan IPB. Bogor.

Soetrisno, K., 2001. Silvika. Bahan Kuliah Fakultas Kehutanan Universitas Mulawarman. Samarinda.

Sutopo, L., 1985. Teknologi Benih. Rajawali. Jakarta.

Triwanto, J., 1997. Pengaruh Konsentrasi Atonik dan Lama Perendaman terhadap Perkecambahan Benih dan Pertumbuhan Semai Gmelina arborea Roxb. Thesis Program Studi Magister. Universitas Mulawarman. Samarinda. 